\title{
Os efeitos da proporcionalidade e do devido processo legal substantivo sobre a ilicitude das provas no processo penal
}

\author{
Proportionality and substantive due process of law effects over penal process illicit proofs
}

\author{
Humberto Lima de Lucena Filho ${ }^{1}$ \\ Lauro Ericksen Cavalcanti de Oliveira ${ }^{2}$
}

\begin{abstract}
Resumo
0 devido processo legal é um instituto que fomenta a polêmica nos meandros jurídicos, principalmente quando se trata da sua acepção material. 0 enfoque inicial do presente trabalho é traçar as propriedades essenciais do devido processo legal substantivo para, posteriormente, determinar as bases do princípio proporcionalidade como denominador essencial para a consecução da validade processual. São apresentadas as facetas decomponíveis da proporcionalidade: adequação, necessidade e proibição do excesso. 0 objetivo geral do trabalho em tela consiste em estabelecer as bases teóricas da conceituação da acepção substantiva do princípio do devido processo legal, com as suas aplicações mais amplas. 0 objetivo específico do trabal ho se foca em perscrutar quais são os efeitos decorrentes da aplicação do referido processo na temática das provas ilícitas insertas no direito processual penal, escrutinando as suas possibilidades de alteração prática nessa seara a partir de uma noção interpretativa dos desdobramentos da proporcionalidade decisória nessas premissas básicas de análise. A metodologia de trabalho empregada no presente artigo é composta pela apresentação das premissas teóricas da acepção substantiva do devido processo legal combinadas com os delineamentos de proporcionalidade ínsitos a esse princípio em aplicação direta na análise legal de procedimentos processuais penais específicos na colheita de provas, para verificar as possibilidades práticas de sua influência em tais processos e como eles são afetados pelas referidas concepções técnico-teóricas. A partir desses elementos busca-se dar uma maior dinâmica social à aplicação da proporcionalidade como função prática imprescindível para a devida manutenção material do devido processo legal.
\end{abstract}

1 Oficial de Justiça Avaliador Federal do Tribunal Regional do Trabalho da 21a Região, Professor colaborador/convidado e palestrante da EFE TRÊS-D Publicações Jurídicas Ltda, Professor universitário do curso de Direito da Faculdade Natalense para o Desenvolvimento do Rio Grande do Norte - FARN. Bacharel em Direito pela Universidade Federal do Rio Grande do Norte - UFRN (2006). Especialista em Direito e Processo do Trabalho pela Universidade Potiguar - UnP/Laureate International Universities (2009). Mestrando em Direito Constitucional, na linha de pesquisa Processo e Garantia de Direitos, pelo Programa de Pós-Graduação em Direito da Universidade Federal do Rio Grande do Norte - PPGD/UFRN (2010).

${ }^{2}$ Analista Judiciário especialidade Execução de Mandados do Tribunal Regional do Trabalho da 3a Região (TRT3/M G). Bacharel em Direito pela Universidade Federal do Rio Grande do Norte - UFRN (2008). Especialista em Direito do Trabalho pela Universidade Cândido Mendes - UCAM -RJ (2010). Mestrando em Filosofia, na linha de História e Crítica da Metafísica, pelo Programa de Pós-Graduação em Filosofia da Universidade Federal do Rio Grande do Norte - PPGFIL-UFRN.

Revista de Direito Púbuco, LondRINA, V. 6, N. 3, P. 168-190, OUT/DEZ. 2011. 
Palavras Chave: Devido Processo Legal Penal; Princípio da Proporcionalidade; Provas llícitas.

\begin{abstract}
The due process of law is an institute that inflicts some controversy in the law system, mainly about its substantive form. A wrong law custom prompts the majority of jurists to just consider the procedural aspect of this vast principle. The initial effort of this work is to point out all the essential properties of the substantive due process to, afterwards, determinate the bases of the reasonableness principle as a pivotal denominator to a procedural validity consecution. The decomposable facets of reasonableness are presented, such as: adequateness (suitability), necessity and excess prohibition. The general objective consists establish the theoretical basis of substantive due process of law conception, with its major and wide appliances. The main objective of this essay focuses on the pursuit of the coming effects of due process of law over the penal process illicit proofs questions, scrutinizing the practical changes on this law field backing up from an interpretative notion of decision and proportionality outspread in these basic premises of analysis. This work methodology is composed by the presentation of theoretical substantive due process of law premises combining it with some proportionality arrangements in direct appliance in legal and penal procedural activities that concern to the illicit proofs evaluation system, just to verify the practical influence of these arrangements in decisory incisions and how they are affected by the commented technical-theoretical conceptions. Starting from these elements, this essay seeks to provide a social dynamism to the appliance of reasonableness as a practical function that is indispensable to the right upkeep of the substantive due process. Then, the effects of these premises are put over the analysis about the illicit proofs inserted in a law process. After presenting the obstructive theory about this kind of proofs (the pure and the moderated one) a quickly match is done, trying to obtain a decreasing level on the subjective opinion of a law sentence (decisum). Thus, the theory of "fruits of the poisonous tree" studied. The work examines the law system to a more complete definition of this institute, projecting it with the elements of reasonableness in confront to the indelible decisory subjectivism. To achieve the presented objectives of this work some jurisprudence texts and practical examples are brought to formalize the procedural input to the mood of certain philosophical aspects of the ethic content of the process and its validity.
\end{abstract}

Keywords: Criminal Due Process of Law; Reasonableness Principle; Illicit Proofs.

\title{
Introdução
}

A temática posta acerca das provas ilícitas é um tema que divide amplamente a doutrina e que, com certeza, não alcança consenso entre aqueles que se aventuram nesta seara. Abstraindo-se de adentrar nos contornos tomados pela matéria segundo a teoria puramente permissiva das provas ilícitas, convém ser de maior aproveitamento cingir 0 
objeto de estudo do presente trabalho à apenas certas considerações concernentes ao princípio do devido processo legal em sua acepção substantiva, bem como também a sua aplicação decorrente por parte da corrente doutrinária denominada de "obstativa temperada".

Primeiramente, há de se ter uma breve exposição da origem do vocábulo do devido processo legal (due process of law), passando por suas espécies aplicativas, chegando ao que hodiernamente é abstraído desse princípio. Bem como se faz mister delinear qual a sua expressividade para a questão das provas ilícitas, uma combinação de sua conceituação com a sua aplicabilidade constitucional. De modo a se pautar por sempre expor os contornos assentes ao vocábulo da proporcionalidade (ou razoabilidade na denominação anglosaxônica do termo) como princípio intrínseco ao sistema constitucional e como vetor de direito fundamental da própria carta magna.

Por fim, são traçadas breves considerações acerca da comunicabilidade das provas ilícitas e de seus desdobramentos para o processo, expondo, por conseguinte, a teoria da árvore dos frutos envenenados (fruits of the poisonous tree ou taint doctrine). Cabendo encetar o breve trabalho com excertos doutrinários e exemplos elucidativos de como a aplicação do princípio da proporcionalidade poderá ter seu caráter subjetivista reduzido por meio de técnicas efetivas de sopesamento e ponderação.

\section{Origem e breves conceituações acerca da acepção substantiva do Devido Processo Legal}

A origem etimológica do devido processo legal (due process of law) remonta à época da Magna Carta, confeccionada em 1215, pelo Rei João Sem Terra (John of England ou simplesmente John Lackland). O primeiro diploma legal formalmente erigido na história da humanidade trazia em seu bojo de determinações que os conflitos existentes deveriam ser resolvidos de acordo com a denominada the law of the land. Algo que trazendo para os dias atuais seria nada mais nada menos que decidir os conflitos tendo como norte o ideal de Justiça. Trilhando a evolução do termo em tela, tem-se que o mesmo findou por ser trazido até a presente data como due process of law, que numa tradução livre e corrente significa 0 "devido processo legal". 


\section{Os efeitos da proporcionalidade e do devido processo legal substantivo sobre a ilicitude das provas no processo penal}

Analisando-se perfunctoriamente, esse princípio ganhou uma roupagem adequada apenas aos seus termos procedimentais. Isto é, os doutrinadores focavam especificamente nos seus termos eminentemente processuais, como garantias intrínsecas ao próprio ser humano e toda conjectura teórica bastante usual ao se falar desse vocábulo.

Todavia, o supracitado princípio do devido legal também assume outra feição, que na verdade é tão importante, ou até mais, que a já referida. Essa outra acepção é denominada de substantiva, e se refere diretamente ao princípio da proporcionalidade ou da razoabilidade. A escolha por uma ou outra determinação terminológica do princípio varia em função da primeira ter origem germânica (Verhältnismäßigkeitsprinzip) e o outro ter origem anglo-saxônica (reasonableness).

Acerca da acepção substantiva do princípio da proporcionalidade (deste ponto em diante usar-se-á apenas o vocábulo proporcionalidade no decorrer do presente texto para representar a acepção substantiva do devido processo legal, por ser esta a expressão mais bem retrata a expressividade do termo) tem-se que o devido processo legal se apresenta também no campo do direito material, salvaguardando garantias constitucionais individuais e coletivas, a exemplo do livre acesso ao Judiciário para a obtenção de uma sentença justa. Sem essa possibilidade de garantia mais ampla e extensa, tal como a cobertura constitucional do tema garante, seria inócuo se pensar a própria dignidade humana como princípio regente de todas as relações jurídicas encetadas na sociedade hodierna.

Em adição ao tema, a melhor doutrina ensina que a cláusula do Due Process of Law não se refere apenas a tutela processual. 0 Substantive Due Process of Law consiste no alargamento do princípio e sua atuação na defesa de todas as garantias constitucionais do cidadão na seara do direito material (NERY JÚNIOR, 1996, p. 34). Vetorizando esta aplicação, pode-se mensurar a razoabilidade do exercício do poder de polícia e até mesmo de atos legislativos, como é corrente no direito norte-americano. 0 Procedural Due Process of Law é deveras restritivo e atine apenas às garantias processuais do indivíduo.

Destarte, é por meio deste princípio em sua forma substantivada que se consegue operar o chamado sopesamento de outros princípios e direitos, isto porque, tal princípio nunca se choca com outro princípio, seja ele constitucional ou não, porque a proporcionalidade a ser aplicada é sempre implica em fracionar o objeto (ou objetos) da análise. Nesse sentido, como bem assevera Márcia Zollinger (2006, p. 109), deve haver o 
sopesamento das vantagens e desvantagens ocasionadas pela restrição a um direito fundamental e a realização de outro direito fundamental que fundamenta a adoção da medida restritiva (ou até mesmo uma medida punitiva, há de se acrescentar). Não havendo, portanto, uma parte estanque no princípio em tela, sendo sua adequação sempre possível aos casos concretos, comumente por via do referido ato de sopesar.

O princípio da proporcionalidade em seus moldes de aplicação prática absorve uma representatividade tripartite em: adequação (Geeignetheit, do original em alemão), exigibilidade ou necessidade (Erforderlichkeit, original em alemão), e proporcionalidade em sentido estrito (que alude ao já citado verbete da Verhältnismäßigkeit). Ressalve-se ainda a nomenclatura utilizada por José J. Gomes Canotilho (2002, p. 266) o qual se vale do vocábulo proibição do excesso para se referir à proporcionalidade, numa clara denominação de sentido negativista, quase platônica em sua reciprocidade discursiva, a qual ele extrai originalmente da doutrina alemã, lá nomeada de Übermaßverbot.

Quanto a estas formas aplicativas inserta neste princípio, há de se enunciar, tal como o fazem Gilmar Mendes, Inocêncio Coelho e Paulo Gustavo Gonet Branco (2008, p. 330) que:

O Tribunal Constitucional Alemão (Bundesverfassungsgericht) explicitou que os meios utilizados pelo legislador devem ser adequados e necessários à consecução dos fins visados. 0 meio é adequado se, com a sua utilização, o evento pretendido pode ser alcançado; é necessário se o legislador não dispõe de outro meio eficaz, menos restritivo aos direitos fundamentais.

0 molde do "subprincípio" da proporcionalidade em sentido estrito é que vai estar exatamente adstrito ao princípio do devido processo legal na forma substantiva. De maneira que se visa afastar cada vez mais o conteúdo do decisum de um subjetivismo execrável. Outrossim, há de se considerar a habitualidade de tal aplicabilidade subjetiva na resolução do conflito hipotético, a ser efetuada tanto pelo legislador quanto pelo operador do direito, como algo deveras danoso para o resguardo substantivo do provimento jurisdicional.

Não obstante, tal como enuncia Carlos Roberto Siqueira Castro (2006, p. 145), a razoabilidade (ou proporcionalidade, tal como se é defendido acima) finda por delinear contornos claros à discricionariedade do exercício da função estatal de editar normatizações e a sua conseqüente transformação em instrumentos legais, as quais assumem funções 


\section{Os efeitos da proporcionalidade e do devido processo legal substantivo sobre a ilicitude das provas no processo penal}

reguladoras das condutas sociais, desde que elas acabem por implicar em um tratamento homogêneo para situações distintas. Ainda cabe se fazer uma breve referência ao acréscimo dado por José Afonso da Silva (2006, p. 131), o qual compreende, explicitando melhor a própria etimologia da "substantividade" (para se utilizar de uma linguagem fenomenológica do direito), que a aplicabilidade do devido processo legal pode se ater, também, à igualdade substancial das situações levadas em consideração. A partir dessa pontuação de Silva, podese compreender que a sua incisão prática, tal como se explicitará melhor mais à frente, quando se tratar dos efeitos desse princípio, à questões decisórias e reverberantes em procedimentos processuais propriamente ditos, e não apenas se referir a elementos teóricos de fundamentação normativa abstrata.

Esse desenvolvimento teórico é o conectivo essencial da referência legal da proporcionalidade inserta na Constituição da República, em seu artigo 50, inciso LIV, que em síntese enuncia que ninguém será privado da liberdade ou de seus bens sem 0 devido processo legal.

Tal disposição legal, a qual lastreia positivamente o princípio da proporcionalidade, é que permite que o processo legal seja um elemento de regulação razoável das leis que porventura sejam editadas, conferindo um caráter proporcional a sua aplicação, conferindo unidade de aplicação aos princípios constitucionais em suas frações ideais variáveis em cada caso concreto.

\section{Os efeitos da proporcionalidade aplicada ao devido Processo Legal e a problemática das provas ilícitas}

A Constituição na República Federativa do Brasil de 1988, em seu artigo 50, inciso LVI estabelece peremptoriamente que "são inadmissíveis, no processo, as provas obtidas por meios ilícitos". O diploma constitucional hodierno exclui de modo severo e rígido a possibilidade de se utilizar a prova produzida em confronto com o direito. Nesse mesmo horizonte, o artigo 157 do Código de Processo Penal estatui que são inadmissíveis as provas ilícitas obtidas com a violação de normas constitucionais e legais, bem como as provas delas derivadas.

Destarte, de maneira introdutória acerca da inadmissibilidade dessas provas ilícitas, é de grande valia trazer o perfunctório, porém bastante elucidativo, magistério de Luiz 
Francisco Torquato Avolio (1999, p. 76) acerca do tema, o qual comenta que a teoria da proporcionalidade ou da razoabilidade consiste, exatamente, em uma construção doutrinária e jurisprudencial que se coloca nos sistemas de inadmissibilidade da prova obtida de maneira ilícita, possibilitando, em virtude de uma vedação do exercício probatório, que se proceda a uma escolha, nos casos concretamente analisados, entre os valores relevantes e de cunho constitucional trazidos à baila.

Utilizando-se dos conceitos anteriormente expostos (na seção precedente, precipuamente), tem-se como ótimo meio de experimentação fatual do princípio da proporcionalidade a questão das provas ilícitas usadas em juízo. Em tempo, o conceito de "ilicitude" abordado aqui se refere especificamente ao meio de produção das provas, o ingresso delas no seio processual se dá de forma escorreita - o problema não se refere ao modo de entrada delas no processo - , o vício fica adstrito à gênese da prova. Para as provas que ingressam de maneira inadequada ao processo é comum atribuir a denominação de ilegítima, e não ilícita, embora ambas, em regra, sejam vedadas. Nuvolone (apud GRINOVER, FERNANDES; GOM ES FILHO, 2001, p. 131) coloca que as provas ilícitas são espécies de privas vedadas, que compreendem ainda as provas ilegítimas como segunda espécie. Ainda que seja válida essa diferenciação, essa distinção ainda não é boa na prática o suficiente para ser totalmente definitiva. Assim, é importante trazer o acurado magistério de Fernando de Almeida Pedroso (1994, p. 163), segundo o qual a prova ilegal é qualquer prova produzida com a violação de leis, sejam elas de direito material ou processual. É o gênero de vício da qual derivam as provas ilegítimas e as ilícitas. A prova que tem a sua produção com infração das disposições processuais é denominada de prova ilegítima, ou seja, ela está prestes a entrar na sistemática processual, e a sua apuração é feita de forma viciada (como exemplo, o caso de interrogatório de menor sem que lhe seja nomeado curador). Já a prova rotulada como ilícita é aquela que é obtida por meio da infração de disposições de direito material.

Desta feita, há de se atentar que nada impede que uma prova seja, concomitantemente, ilegítima e ilícita, essas duas espécies da prova ilegal podem estar contidas em um mesmo ato. Nesse sentido, bem assinala Ada Pellegrini Grinover (1982, p. 128) que: "determinadas provas, ilícitas porque constituídas mediante a violação de normas materiais [...], podem ao mesmo tempo ser ilegítimas, se a lei processual também impede a sua produção em juízo". Destarte, não há uma pressuposição de que a prova produzida 


\section{Os efeitos da proporcionalidade e do devido processo legal substantivo sobre a ilicitude das provas no processo penal}

ilicitamente seja algo vedado pela sistemática processual vigente, mas nada impede que sejam estabelecidas regras mínimas para a produção de provas que venham a tornar as provas ilícitas também ilegítimas.

Nesse passo, vale destacar que Andrey Borges M endonça $(2009$, p. 33) bem salienta que se a ilicitude das provas se der em sua obtenção em violação a uma norma, seja ela legal ou constitucional, deverá ser aplicada, como consequência desse vício, a inadmissibilidade da prova, e não a mera nulidade, já que a inadmissibilidade acarreta o desentranhamento da prova dos autos. De outra banda, no entanto, caso a violação da norma não se dê no tocante à obtenção da prova, e sim quanto a sua introdução no processo (como, por exemplo, o caso de juntada de prova em plenário do júri sem que haja a devida observância do artigo 479 do Código de Processo Penal ${ }^{3}$ ) haverá apenas a ilegitimidade, cujo regime de sanção a ser aplicado é o de nulidade, e não o de inadmissibilidade.

Ao se tratar desse tema, há de se fazer apenas uma breve ressalva sobre mais um termo classificatório trazido à baila por Paulo Rangel (2009, p. 431), o qual fala da possibilidade das provas serem consideradas irregulares, um conceito diverso dos conceitos de ilegitimidade e ilicitude anteriormente tratados, embora todos eles sejam espécies do gênero da ilegalidade das provas. Para o referido jurista, há irregularidade na prova nos casos em que, não obstante elas sejam admitidas pelas normas processuais penais, tal escorço probatório foi colhido com infringência de formalidades legais existentes. Assim, embora a lei processual admita (ou ao menos, não proíba) um certo tipo de prova, ela exige, para a sua validade, o cumprimento de determinadas formalidades que não foram (ou não estão sendo cumpridas) no momento do colhimento da prova. 0 exemplo de prova irregular fornecido por Rangel é o da busca e apreensão domiciliar (disposta no artigo 240 do Código de Processo Penal - CPP) em que se apreende coisa diversa da descrição feita no mandado (disposição do artigo 243 do $\mathrm{CPP}^{4}$ ). Deste modo, caso o mandado identifique uma arma de fogo a ser apreendida (diligência probatória regular), não poderá a força policial apreender

\footnotetext{
${ }^{3}$ Artigo 479 do Código de Processo Penal, in verbis: "Durante o julgamento não será permitida a leitura de documento ou a exibição de objeto que não tiver sido juntado aos autos com a antecedência mínima de 3 (três) dias úteis, dando-se ciência à outra parte".

${ }^{4}$ Artigo 243 do Código de Processo Penal, in verbis: "O mandado de busca deverá: I - indicar, o mais precisamente possível, a casa em que será realizada a diligência e o nome do respectivo proprietário ou morador; ou, no caso de busca pessoal, o nome da pessoa que terá de sofrê-la ou os sinais que a identifiquem; II - mencionar o motivo e os fins da diligência; [...]",
} 
uma camisa suja de sangue na casa a ser buscada, sob pena de vilipendiar a regra constitucional da inviolabilidade do domicílio por via transversa, e a prova ser, segundo o jurista em tela, considerada irregular.

A existência, por si só, de qualquer prova que desafie os contornos de legalidade (tanto na seara material quanto processual) é algo tido como uma manifestação espúria do direito (CASTRILLO; MORATO, 2007, p. 52), pois, ainda que no campo fático ela seja algo valorativamente relevante, juridicamente ela não passa de uma distorção não relevante para fins decisórios. Seguindo essa trilha de interpretação, Luís Pinto Ferreira (1995, p. 180) deixa assente que a inadmissibilidade de provas obtidas, no processo, por meios ilícitos, é a transposição em nível constitucional da orientação firmada na doutrina e na jurisprudência que essa manifestação viciada não deve servir para fins de tomada de decisão nem de fundamentação probatória dos magistrados. Em síntese, cabe também a salvaguarda constitucional para que esse tema seja protegido e tratado sempre com grande cautela e importância, dada a sua reverberação no campo prático, a qual pode determinar a justiça ou a injustiça no julgamento de um caso concreto.

Na verdade, essa limitação à busca da verdade real no processo penal, e, por conseguinte, a própria limitação na produção do escorço probatório, é a consolidação do entendimento de que a verdade processual não é um valor absoluto e, por isso, não tem de ser investigada a qualquer "preço", mormente quando esse "preço" é o sacrifício de direitos fundamentais (SILVA, 1996, p. 122).

Ainda que se possa parecer que a aplicação da restrição da obtenção das provas ilícitas em combinação com o devido processo legal em sua acepção substantiva possa parecer dar azo a que se pensa que isso favorece apenas aqueles que se encontram no polo passivo dos processos penais, Antônio Magalhães Gomes Filho (1997, p. 36) é firme em asseverar o contrário, segundo este autor o critério da proporcionalidade, na verdade, encontra agasalho nos textos legislativos destinados a dar maior severidade à repressão do crime organizado, do tráfico de entorpecentes e de outras expressões mais agudas da criminalidade. 0 autor em comento cita, como exemplo de seu entendimento, o direito estrangeiro, mais especificamente a lei antimáfia italiana (um dos exemplos mais eficientes da repressão legal a esse tipo de crime em todo o mundo), o Decreto-Lei no 306 de 08 de junho de 1992, dentre outros diplomas normativos antiterror de diversos países integrantes 


\section{Os efeitos da proporcionalidade e do devido processo legal substantivo sobre a ilicitude das provas no processo penal}

da União Européia. Esses exemplos servem para elucidar que a aplicação desse subprincípio, tanto na elaboração legislativa, como bem elenca Gomes Filho, como na aplicação prática decisória, podem servir como um instrumento de concretização de justiça e de conseqüente pacificação social, e não, apenas, como entendem alguns, como uma forma de favorecimento de réus em processos penais, uma forma bastante simplória de compreender 0 referido tema.

Por isso mesmo a questão da utilização das provas ilícitas sempre toca em um tema deveras delicado, que é o conteúdo ético do próprio processo e seus rigores formais. Sem dúvida alguma, vários juristas titubeiam ao tratar do tema, seja por não quererem se aventurar em terrenos de maior propriedade filosófica quanto à moralidade ou ética aplicadas ao processo (convém sempre a ressalva que existe uma diferença substancial entre os dois termos quando se está tratando de uma linguagem filosófica apurada, o que, todavia, não é o escopo primordial do presente artigo) ou por aplicarem a regra da moralidade administrativa (inserta no "caput" do artigo 37 da Constituição da República) de maneira resolutiva prática. Outrossim, a questão primordial a ser tratada se refere a sopesar os ditames éticos da utilização desta prova para com a busca da verdade real.

Aqueles que defendem que toda e qualquer prova ilícita seja espargida do processo se baseiam em dois argumentos básicos: o próprio conteúdo ético do processo e a unidade estrutural dele são elementos essenciais para obstarem a aceitação desse tipo de prova. 0 conteúdo ético proíbe que a ilicitude, mesmo que indiretamente, contamine o trâmite processual; já a unidade do processo jurisdicional, por sua vez, impediria que o acúmulo de exceções em aceitar provas ilícitas virasse a regra a ser aplicada.

Essa corrente recebe a denominação de obstativa pura (M ACHADO, 2009, p. 370), e poderia até ser aplicada com propriedade - num plano teórico ideal -, todavia, o que impede que sua plena e irrestrita aplicabilidade é justamente um de seus argumentos, 0 conteúdo ético. Como a definição corrente no meio jurídico de moralidade e de ética é deveras incipiente, em faces de perquirições filosóficas mais acuradas - por exemplo, 0 rigorismo formal de um processo judicial jamais poderá estar em consentâneo com as regras de um imperativo categórico tal como definido pelo filósofo alemão Immanuel Kant (2003, p. 79), uma vez que, por mais que o magistrado se esforce nesse sentido, o máximo que ele conseguirá é a aplicação de um imperativo hipotético, e talvez nem isso. 
Assim, há uma inclinação recorrente na doutrina a se posicionar pela adoção de uma oposição branda à possibilidade de se utilizar provas ilícitas no processo, tal teoria é usualmente traduzida como sendo uma corrente obstativa temperada, isto é, em certas ocasiões será aceitável que se use regras do princípio da proporcionalidade para que a prova seja aceita, e que ela tenha plenos efeitos no processo em que foi usada, podendo até mesmo ser o elemento decisório chave do mesmo.

Como já enunciado, o princípio da proporcionalidade reverberará de maneira contundente quando se tratar de provas ilícitas. A técnica do sopesar os interesses intrínsecos à aceitação ou não da prova é que deverão estar no enfoque principal das questões abordadas. A melhor interpretação das regras constitucionais enuncia que não há direito fundamental absoluto. Destarte, partindo desta definição é que poderá ser aplicado o sopesar, outrossim, deverá haver um balanceamento de evidências entre os direitos defendidos.

Para a correta aplicação do princípio da proporcionalidade como um elemento distintivo dos casos plausíveis de serem tratados segundo essa linha de análise, Costa Andrade (apud SILVA JÚNIOR, 2008, p. 517) traça quatro pontos de básicos que devem ser levados em conta.

0 primeiro deles diz respeito ao interesse in concreto da persecução penal. Esse primeiro elemento básico é uma pontuação e uma crítica direta às políticas públicas mais abstratas de controle penal. Ele dá uma maior importância para as variantes circunstancias dos casos concretos para que o magistrado possa aferir, em sua colocação específica daquele caso, se a persecução penal está sendo algo realmente imprescindível e interessante para o plexo de anseios sociais trazidos a baila naquele caso concreto. Para analisar os casos penais seguindo essa concepção de interesse e utilidade o magistrado não pode olvidar que o direito penal deve ser tido como a ultima ratio, a solução final mais extremada para os distúrbios sociais. Sem essa concepção de que a aplicação penal deve ser uma excepcionalidade, é impossível que esse elemento básico da proporcionalidade seja observado com eficiência.

0 segundo dos elementos elencados por Costa Andrade faz referência à gravidade da lesão à norma. A proporcionalidade, nesse caso, servirá para fazer a gradação da lesividade do ato praticado quando confrontado com a abstração contida no cerne 


\section{Os efeitos da proporcionalidade e do devido processo legal substantivo sobre a ilicitude das provas no processo penal}

normativo. Esse é um exercício hermenêutico de grande monta e de um grau de dificuldade relativamente elevado, pois, não basta que o juiz conheça o comando normativo a ser aplicado em sua decisão, ele precisa, antes mesmo de decidir, observar a relevância prática do caso, da conduta do agente, e das demais variantes fáticas que podem alterar os rumos da sua decisão.

0 elemento seguinte a ser analisado diz respeito ao bem jurídico tutelado pela norma constitucional violada. É esse critério de análise que determina a ponderação do princípio da proporcionalidade na análise das provas ilícitas e, em maior amplitude, na própria decisão a ser exarada pelo magistrado. É nesse momento que o juiz se encontra incumbido de fazer as ponderações devidas entre os bens jurídicos colocados em tela, e, por eles decidir, sem que essa sua decisão seja algo inclinado para o afastamento de um dos bens trazidos à testilha, e, sim, que a sua decisão se paute no princípio da proporcionalidade para promover o prestígio entre um dos bens passíveis de serem escolhidos em sua atividade jurisdicional derradeira.

0 último ponto levantado pelo jurista brasileiro anteriormente citado está adstrito à questão de haver uma carência de tutela do interesse lesado. Nesse caso, a decisão mais proporcional não seria continuar a persecução penal no sentido diametralmente oposto à inexistência de uma tutela jurídica específica do interesse vilipendiado, sendo mais escorreito, nesse caso, e dada as possíveis particularidades desse panorama, prezar pela aplicação da proporcionalidade tal como delineada por ora.

Como já denotado, uma maneira bastante elucidativa de se proceder à resolução desses impasses jurídicos é se valer do elemento denominado de ponderação dos preceitos jurídicos. Tal prática de ponderar se calca numa ciência da articulação de princípios que não possuem uma hierarquia formal rigidamente posta entre eles. Assim, valendo-se desse elemento conclusivo obtém-se a denominada concordância prática em casos concretos. De fato, se finda por alcançar aquilo que Zagrebelsky (apud DANTAS, 2005, p. 279) denomina de o "balanço entre bens jurídicos conduzido pelo princípio da proporcionalidade". Isto é, a ponderação normativa busca sempre a confluência dos preceitos jurídicos com a expectativa de aninhá-las nos ditames práticos de sua concordância.

Há de se ressalvar que essa técnica estratégica de concretização não emerge simplesmente de elementos meramente abstratos ou se fundamenta numa análise 
usualmente dogmática textual. A ponderação ${ }^{5}$ nos dizeres de David Diniz Dantas (2005, p. 280) possui uma tríplice contingência. 0 primeiro intento é para se resolver os "casos de tensão" entre direitos constitucionais e direitos fundamentais (Grundrecht), sendo tais direitos pertinentes àqueles relativos a personalidade, desde que seja constitutiva da dignidade, da autonomia e da alteridade da pessoa humana (ALEXY, 1986, p. 50).

Trilhando a esteira da ponderação, Cássio Scarpinella Bueno (2007, p. 100), mesmo se utilizando de um termo ligeiramente diverso (preponderância) analisa que as delimitações de instituição de "regra" da proporcionalidade é capaz de ofertar elementos criteriosos e mais objetivos possíveis, os quais, precipuamente, deverão ser utilizados para solucionar os impasses de preponderância da mais variada miríade de princípios jurídicos aplicáveis em cada caso concreto. Ademais, esta regra que deve ser utilizada em todos os casos em que 0 intérprete ou o aplicador do direito não conseguir compatibilizar os princípios conflitantes. 0 desdobramento dessas pontuações desemboca no entendimento que o método de constatação de qual princípio deve prevalecer em cada caso concreto, destarte, tal aplicação prática repousa na "regra da proporcionalidade". Outrossim, a sua correta aplicação depende da qualidade da motivação das decisões jurisdicionais, as quais, seguindo essas premissas teóricas da qualidade substantiva do devido processo, são capazes de fornecer uma prestação jurisdicional mais efetiva e mais contundente, do ponto de vista do "acerto jurisdicional decisório".

Outra contingência é a inexistência de uma ordenação in abstracto. A última contingência na verdade é uma decorrência lógica da segunda, uma vez que se pauta na impossibilidade de simples subsunção do caso concreto a norma dada a estrutura típica das normas constitucionais em tela.

Já na primeira contingência extrai-se que a dificuldade de julgamento reside na própria apreciação subjetiva dos casos práticos, isto é, o imbróglio decisório se localiza na

\footnotetext{
${ }^{5}$ Assim como ocorre com o termo "proporcionalidade" e "razoabilidade", a ponderação possui dupla denominação com origens etimológicas diversas. Na literatura jurídica alemã ela é denominada de abwagung e assume uma feição mais próxima de uma visão paradigmática da interpretação constitucional. Já na doutrina americana a ponderação é denominada de balancing, numa livre tradução: balanceamento. Tal emprego terminológico finda por assumir um caráter reminiscente da própria origem imagética da Justiça, seu caráter pendular de balança com pesos e medidas.

${ }^{6}$ Como bem destaca a jurisprudência do pretório excelso brasileiro, "a utilidade do juízo de proporcionalidade ou de razoabilidade no exame das normas conformadoras de direitos fundamentais, que deveria passar pelo crivo dos critérios da adequação, da necessidade e da proporcionalidade em sentido estrito". (RE 590880/CE, Min. Ellen Gracie, j. 20.02.2010. DJ. 24.3.2010)
} 


\section{Os efeitos da proporcionalidade e do devido processo legal substantivo sobre a ilicitude das provas no processo penal}

própria concretização da Constituição. Isto é comumente observado na própria essência de normas legais editadas com o fito de completar, densificar e concretizar um direito fundamental (M ENDES; COELHO; BRANCO, 2008, p. 214). Desta feita, para dirimir casos conflitantemente caóticos no plano prático, 0 decisum deve se ater nas diretrizes máximas ponderativas.

A diretriz formalizada anteriormente também se aplicará de maneira cogente as duas outras contingências que em muitos aspectos se aproximam e se tangenciam. Bem porque ao se extrair a abstração da ordenação normativa depreende-se que a mera subsunção casuística não será bastante para que se galgue a completude sistemática da estrutura típica e legal.

Nesse horizonte, David Diniz Dantas (2005, p. 281), já previamente citado e comentado em momento anterior nesse presente artigo, prossegue dizendo que em três casos será possível a concretização direta de um princípio por parte do juiz ou do tribunal em seu decisum: na lacuna normativa, seja ela de natureza explícita, axiológica ou ontológica; quando se tratar de tipos normativos vagos ou plurívocos e plurisemânticos; e, quando a densificação normativa operada pelo legislador dor inconstitucional, hipótese que efetivamente também se conduz a uma lacuna normativa.

Desta feita, afigura-se que em várias dessas situações hipotéticas a próp ria atuação legislativa pode levar a proposição de meios de produção de provas que sejam tidos por ilícitos e por vezes inconstitucionais, quando densificam erroneamente certa matéria, ou até mesmo revestem indevidamente de idoneidade certas práticas que levaram a juízos casuísticos contraditórios ou francamente insatisfatórios do ponto de vista interpretativo constitucional.

Isto não significa dizer que nos casos hipotéticos descritos sempre será admissível a prova obtida por meios ilícitos. É nesse sentido que deverá se buscar a redução dos elementos subjetivos de análise. Em regra, esses elementos jamais conseguirão ser totalmente extirpados ou purgados, pela simples questão de que é impossível que regras universais de aplicação lógica sejam traçadas (não se trata de um processo autômato ou matemático, no qual um robô poderia fazer as vezes do juiz da causa). Até porque, numa concepção filosófica fregeana Evandro Carlos Godoy (2009, p. 96) destaca que existem elementos não-lógicos, que funcionando harmonicamente sob o ponto de vista semântico, 
ainda conduzem a objetos de valores de verdade válidos, algo que de maneira alguma vem a macular a lógica formal do processo. Um ótimo exemplo desses elementos que fogem à principiologia tripartite da lógica aristotélica é justamente a inquirição de testemunhas quando o fato narrado dependa de certas idiossincrasias próprias do objeto relatado ${ }^{7}$.

De toda forma, é possível sim proceder à redução destes elementos marcantes do subjetivismo, e o próprio princípio da proporcionalidade fornece os subsídios para tanto. As aplicações acessórias da adequação - observando a não imposição limitações desarrazoadas, principalmente, sobre os direitos adquiridos vested rights (BITTAR, 1996, p. 557) -, da necessidade - a qual condiz com o meio mais idôneo e a menor restrição possível para se alcançar o objetivo decisório pretendido (BARROS, 2003, p. 81) e do corte do excesso são fundamentais nesse sentido, já que fornecerão linhas objetivas de atuação do magistrado, que com a sua perspicácia analítica deverá observar em quais casos as provas ilícitas deverão ser admitidas para que a verdade real do caso concreto possa emergir.

\section{A Teoria da Árvore: os Frutos Envenenados e a sua relevância para a análise do Princípio da Proporcionalidade}

A teoria da árvore dos frutos envenenados (fruit of the poisonous tree doctrine ou taint doctrine) se erige como uma tentativa de explicação da comunicabilidade entre 0 vício contido numa prova e a decorrência de influência sobre as demais que lhe estão adjuntas.

Outrossim, da mesma maneira que quase todos os seres vivos do reino M etaphyta distribuem sua seiva bruta por todas as ramificações chegando até seus frutos, a prova ilícita finda por contaminar todas as outras provas que estejam adstritas a ela. Ou seja, toda prova

\footnotetext{
${ }^{7}$ Um caso prático recorrente na Justiça do Trabalho ocorre quando o reclamante pleiteia uma resolução contratual por rescisão indireta, isto é, quando a culpa na dispensa é do empregador, e como causa de pedir remota alega assédio moral. Por vezes as testemunhas do reclamante são, no geral, pessoas bem apessoadas e de grande apelo pela aparência, algo que denota, ou ao menos induz a crer que seriam "sujeitos assediáveis", sexualmente falando, já que possuem intrinsecamente características atrativas do ponto de vista do flerte e do envolvimento carnal. Por outro lado, as testemunhas do reclamado costumam ser postas acima de qualquer suspeita de assédio, isto é, resguardado o juízo subjetivo da escolha, são indivíduos dotados de fealdade explícitas, podendo ser denominados, nesse caso prático, de "sujeitos não-assediáveis". Assim sendo, nessa situação hipotética há um conflito claro de um juízo aparente deveras subjetivo, o qual, indubitavelmente refoge a qualquer assertiva peremptória da lógica aristotélica clássica bem como de qualquer outra interpretação mais moderna filosofia da linguagem aplicada ao direito e ao processo em si. Saliente-se apenas, que uma situação parecida pode acontecer quando se tratar, na seara penal, do tipo contido no artigo 216-A do Código Penal, haja vista que se trata de fatos semelhantes e com a mesma gênese ofensora (resguardo sexual do indivíduo).
} 


\section{Os efeitos da proporcionalidade e do devido processo legal substantivo sobre a ilicitude das provas no processo penal}

que direta ou indiretamente se comunique com uma prova obtida de forma ilícita também será considerada ilícita.

Essa é sem dúvida a conceituação que permeia o senso comum, sendo ainda a mais difundida no Brasil. Isso é na verdade algo deveras danoso para o entendimento e para a aplicabilidade dessa teoria, uma vez que tal disseminação doutrinária incompleta enuncia apenas parte da verdadeira teoria da árvore dos frutos envenenados, restando-se incipiente para uma miríade de casos práticos que poderiam ser solucionados com o ensinamento completo da referida teoria.

Isto porque esta teoria comporta duas exceções interessantes e importantes para que a aplicação dela satisfaça os requisitos constitucionais do devido processo legal. É neste ponto excepcional que se desenvolve justamente o princípio da proporcionalidade tão pormenorizado ao longo do presente texto. As duas exceções são: existência de uma fonte independente da prova (independent source) ou que o descobrimento daquela prova fosse algo inarredável do decurso temporal, isto é, fosse inevitável (inevitable discovery).

Ocorre o caso da existência de uma fonte independente quando, por exemplo, 0 Ministério Público fundamenta a sua pretensão punitiva da persecução penal em provas ilícitas e lícitas. Explicando melhor, isso acontece no momento em que as provas são carreadas para o processo dessas duas formas, tanto ilícita quanto licitamente. Isso porque é possível estabelecer uma desconexão causal entre a qualificação lícita ou ilícita da prova, de modo que a prova ilícita não chega a contaminar as demais provas obtidas licitamente. Segundo Paulo Rangel (2009, p. 437), esse nexo de causalidade que deve existir é a "linha que liga a colheita de uma prova à obtenção de outra". Destarte, é como se a independência entre as provas (pelos meios empregados em sua obtenção) fosse bastante para apartá-las em duas categorias distintas, algo bem prático na lida do magistrado na apuração das mais diversas estirpes probatórias que podem ser juntadas aos autos processuais. Essa teoria encontra espeque no artigo 157, nos parágrafos 1 e e 20 do Código de Processo penal, os quais consideram como fonte independente aquela que por si só, seguindo os trâmites típicos e de praxe, próprios da investigação ou da instrução criminal, seria capaz de conduzir ao fato objeto da prova, sendo, portanto, independente da derivação de uma prova ilícita previamente trazida aos autos. 
O descobrimento de uma prova dentro dos procedimentos de apuração penais pode ser algo tido como inevitável nos limites lógicos da razoabilidade. Em consentâneo com essa premissa que foi desenvolvida a teoria da descoberta inevitável (inevitable discovery). Tal como a teoria acima exposta (a da fonte independente), a teoria da descoberta inevitável é uma forma de mitigar a teoria da árvore dos frutos envenenados, pois, sem embargo de haver um procedimento empregado para o descobrimento de um fato a ser levado aos autos, é possível que a prova a ser daí extraída seja tida como lícita para todos os fins legais.

Apesar de serem aparentemente semelhantes, as teorias da fonte independente e da descoberta inevitável são diversas em sua essência. 0 elemento fundamental na distinção entre elas reside na necessidade de se proceder à apuração probatória para se chegar ao fato que deve ser extraído e levado ao processo para servir de sustentáculo para a defesa ou para a acusação do réu. Isto porque, na teoria da fonte independente, é imperioso que se proceda à averiguação probatória do fato investigado. Ou seja, necessita-se que a apuração do fato seja feita para se saber se ele seria realmente descoberto de forma independente da derivação ocorrida e advinda da prova ilícita carreada aos autos. Já na teoria da descoberta inevitável não é necessário que sejam empregados tais métodos empiristas para se saber que a inevitabilidade já era uma constante na apresentação e utilização da prova, pretensamente, ilícita. Assim, prescinde-se que o transcurso dos procedimentos probatórios encontrem uma fonte independente para aquela determinada prova, é necessário somente que o seu descobrimento seja tido como inevitável, dentro dos limites do hipoteticamente factível, tal como bem destaca Maximiliano Hairabedián (apud SILVA JÚNIOR, 2008, p. 505). Assim sendo, é fácil compreender que a descoberta inevitável é apenas uma abstração teórica de uma sucessão encadeada de fatos que possam vir a produzir uma prova lícita, mesmo que dentro dessa sucessão lógica de elementos fáticos haja a produção de outras provas que venham a ser tidas como ilícitas, e, por conseguinte, descartadas do processo de avaliação e pontuação da importância dos fatos provados ao final do processo. Como bem complementa Antônio Alberto M achado (2009, p. 372), admite-se a utilização de uma prova revelada por uma prova ilícita, desde que se demonstre que a comprovação do fato seria inexorável, e, fatalmente, decorreria da atividade probante realizada de praxe pela investigação ou pela instrução criminal regularmente desenvolvida pelos órgãos judiciais. 


\section{Os efeitos da proporcionalidade e do devido processo legal substantivo sobre a ilicitude das provas no processo penal}

Desta forma, o vício contido numa prova não se transmite de forma absoluta e ilimitada a outra que dela derive, nos dois casos citados há a regra prevalente de que de forma proporcional ao surgimento da prova de maneira que ela se aparte do vício, a prova obtida poderá ser usada em juízo de maneira plena. Esse entendimento também é esposado pelo pretório excelso, como se depreende de breve análise de seu arcabouço jurisprudencial ${ }^{8}$.

Como bem destaca o emérito doutrinador Walter Nunes da Silva Júnior ${ }^{9}$, ainda que se possa afirmar que o pretório excelso brasileiro tenha adotado a teoria da árvore dos frutos envenenados, ele contemporizou com ela (na verdade, com os seus efeitos, para se ser mais apurado tecnicamente) ao argumentar que a prova somente poderá ser eivada absolutamente de um vício indelével de ilicitude quando a sua derivação depender unicamente daquele substrato factual contaminado. Tal entendimento é bastante adequado com a sistemática das fontes independentes, uma vez que ela enuncia que mesmo nos casos em que a prova derivada guarde alguma relação adstrita com a prova ilícita, aquela não pode ser declarada, de plano, como ilícita sem que seja feita a averiguação de que sua existência depende, ou não, de modo exclusivo, desta que se encontra inquinada de vício insanável de legalidade.

Há de se ter apenas a ressalva que quando nenhum desses elementos mitigadores se apresentar como factíveis a tornar o caso analisável deve-se seguir de toda maneira o princípio do ônus probatório. Isso é deveras importante em termos práticos, haja vista que a própria principiologia da proporcionalidade poderá ser aplicada nesse caso em benefício do suposto investigado (réu numa determinada ação), uma vez que se a prova inserta no processo for obtida unicamente por meios ilícitos e escusos, haverá a inexistência de justa causa para o prosseguimento do processo, por inexistência da justa medida entre o que se apurou e o próprio conteúdo mínimo ético do processo. Esse é justamente o entendimento do Supremo Tribunal Federal quando está a julgar pedidos de trancamento de ação penal

\footnotetext{
${ }^{8}$ SUPREMO TRIBUNAL FEDERAL - HABEAS CORPUS - DENÚNCIA. RECEBIMENTO. BUSCA E APREENSÃO REALIZADA EM DESACORDO COM A DETERMINAÇÃO JUDICIAL. EXISTÊNCIA DE PROVA AUTÔNOMA. Evidenciada a existência de prova autônoma, descabe a pretensão de anular a decisão de recebimento da denúncia, sob a alegação ter sido o mandado de busca e apreensão cumprido em desacordo com a determinação judicial de que os policiais se fizessem acompanhar de duas testemunhas. Ordem não concedida. (HC 84.679/MS. T1. Relator : M in, Eros Grau. j. 09/11/2004. DJ. 12/08/2005). [Grifos do autor].

${ }^{9}$ SILVA JÜNIOR, Walter Nunes. Op. cit., p. 504.
} 
em Habeas Corpus $^{10}$ em que se vincula unicamente provas que não se inserem nas hipóteses de mitigação trazidas pela teoria da árvore dos frutos envenenados.

Ao falar brevemente da proporcionalidade em referência à questão das nulidades no processo penal, Ada Pellegrini Grinover, Antonio Scarance Fernandes e Antonio Magalhães Gomes Filho (2001, p. 136) destacam que se extraem desse princípio certos critérios de análise, através dos quais, o magistrado, sempre em caráter excepcional, e em casos extremamente graves, podem admitir a prova ilícita, baseando-se, para tal, na ponderação do equilíbrio que deve haver entre valores fundamentais contrastantes.

Dentro de uma breve digressão nos meandros da lógica jurídica pode se afirmar que a aplicação da proporcionalidade como regra de aceitação da prova ilícita tende a ser perene sempre que o seu contrário enseje uma desproporcionalidade patente. Ou seja, desde que haja um argumento non sequitur dentro do encadeamento lógico decisório do magistrado. Esse argumento de flagrante desproporcionalidade é sempre ocasionado quando as premissas levadas em conta são válidas, mas a conclusão do argumento é inválida, e no caso, não verdadeira. Por mais que as provas sejam, de fato, ilícitas, a conclusão desse encadeamento de apuração probatória conduz a um juízo de inverdade jurídica, algo que é ainda mais agravado pela questão da distribuição axiológica do argumento jurídico.

Ao se falar desse ponto de aplicação concreta do reconhecimento de provas em contraposição a certos elementos axiológicos, não há como se fugir de brevemente pontuar o tema dos argumentos quase-lógicos do jurista polaco-belga Chaïm Perelman (2004, p. 170). De maneira bastante sucinta e concisa, pode-se partir do princípio que os argumentos quase lógicos "perelmiano", levam em conta que o direito é uma ciência argumentativa, a simples adequação das premissas básicas a uma conclusão lógico-formal leva a resultados práticos desastrosos e pouco eficientes. No caso das provas ilícitas carreadas em um

${ }^{10}$ SUPREM O TRIBUNAL FEDERAL - HABEAS CORPUS. DIREITO PROCESSUAL PENAL. AÇÃO PENAL. NULIDADE. Não há justa causa para a ação penal quando a demonstração da autoria ou da materialidade do crime decorrer apenas de prova ilícita. Tendo em conta essa orientação, a Turma deferiu habeas corpus para, nos termos do art. 386, II, do CPP, absolver condenada nas penas do art. 251, caput, do CPM, por haver efetuado saques na conta de pensionista falecida, nos 5 meses posteriores ao óbito. Tratava-se de writ impetrado contra acórdão do STM que, embora reconhecendo a ilicitude da quebra de sigilo bancário sem autorização judicial, assentara que a confissão posterior da paciente seria suficiente para manter a condenação, aplicando à espécie o princípio da proporcionalidade. Esclareceu-se, ainda, que a mencionada confissão surgira como efeito da prova ilicitamente obtida, sendo razoável supor que não teria sido feita sem a quebra prévia do sigilo. Dessa forma, concluiu que a palavra da acusada, como meio de prova, também padeceria de ilicitude, agora por derivação. Por conseguinte, seriam imprestáveis as provas que fundamentaram a condenação imposta à paciente. (HC 90298/RS, Min. Cezar Peluso. j. 08/09/2009. DJ 19/08/2009. p. 176). 


\section{Os efeitos da proporcionalidade e do devido processo legal substantivo sobre a ilicitude das provas no processo penal}

processo penal, a decisão será sempre baseada nos argumentos quase lógicos tal como explicitados, haja ou não o acolhimento da prova ilícita. Se ela não for acolhida, a verdade real não será alcançada por falta de uma parte constitutiva sua, caso ela o seja, ainda assim a decisão não será totalmente apartada de um argumento quase lógico em função da manifestação espúria da ordem jurídica em aceitar a prova eivada de ilicitude, mesmo que essa seja a melhor opção para o caso concreto que está a ser decidido.

Desta feita, é correto asseverar que o pressuposto analítico de Perelman conduz ao entendimento que não se deve chegar a uma "verdade judicial" pré-estabelecida, por meio da qual o juiz expressaria a vontade da lei, ou algo semelhante a isso (LYCURGO; ERICKSEN, 2011, p. 116). Deste modo, a proporcionalidade na análise de uma prova ilícita pode ser compreendida como sendo um elemento quase-lógico nos moldes "perelmenianos" por não expressar uma simples constatação de verdade (afinal, em última instância, ela é eivada de ilicitude, e não há verdade na ilicitude). Isso sem falar que a aplicação dessa prova permeada pela proporcionalidade dá uma maior singularidade aos casos analisados, sem que isso finde por desembocar num argumento non sequitur de fundamentação decisória e sem que uma injustiça seja perpetrada no plano prático dos efeitos da própria sentença penal.

Para o princípio da proporcionalidade a teoria da árvore dos frutos envenenados age em duas frentes, tanto na regra quanto na exceção. Seus efeitos são notados na regra geral por ela determinada uma vez que a vedação implícita satisfaz a regra de que o vício, em regra, se perpetua na demonstração probatória, não é razoável que ele desapareça num decurso temporal lógico sem nenhuma influência externa. Ao passo que na exceção também se lobriga evidenciar os efeitos da proporcionalidade, uma vez que seria uma regra totalmente injusta e desproporcional se uma prova que produz uma fonte diversa daquela em qual se verificou o vício também fosse fulminada pela simples correlação com a prova ilícita. Semelhante raciocínio deve ser feito com o caso de uma descoberta inevitável, se existia ou não a ilicitude na produção será de pouca importância, uma vez que a lógica investigativa da instrução probatória chegaria àquele mesmo resultado.

\section{Considerações finais}

0 tema proposto coincide com um dos momentos processuais mais importantes, que é justamente 0 da instrução probatória. Não há dúvidas de que a aceitação ou não de 
provas ilícitas é um tema que continuará a gerar polêmica por muito tempo. Os teóricos mais puristas jamais aceitarão que haja uma mácula sequer no processo, por mais que, para que tal regra seja velada e validada tenha que se abrir mão de certas ponderações verídicas a respeito do próprio processo.

0 ponto mais difícil de todo esse imbróglio é ter uma maneira de aplicar a proporcionalidade, leia-se aplicação justa das normas, em casos delicados, sem se recorrer ao subjetivismo exacerbado. 0 subjetivismo é inerente à decisão, todavia, com algumas técnicas de percepção objetiva, ele poderá ser minorado e servirá como elemento norteador das decisões judiciárias, sempre sopesando e fracionando os objetos do decisum.

Assim, a proposição teórica por ora apresentada não visa a fechar o ponto dessa questão levantada como uma aniquilação do subjetivismo na ótica das aplicações decisórias num âmbito abrangente do processo judiciário, bem porque isso seria elevar à enésima potência o nível de presunção inatingível do artigo em tela. De maneira que jogar luzes esclarecedoras sobre o tema é o escopo primordial ao qual se propôs o texto apresentado e o mesmo logra êxito na medida em que denota argumentos que variam desde a aplicação da lógica jurídica aos casos concretos até mesmo à praticidade pragmática utilitarista do princípio da proporcionalidade em suas mais diversas acepções descritas.

Conclui-se, desta feita, que é possível acolher prova ilícita em processos judiciais como uma exceção, a qual deverá sempre ser sopesada e analisada segundo os critérios enunciados na teorética do princípio da proporcionalidade, pois, se de outra maneira sua inserção for feita dentro do ordenamento jurídico pátrio estar-se-ia despojando de todo garantismo necessário para que a decisão jurisdicional seja minimamente razoável.

\section{Referências}

ALEXY, Robert. Teoria de los Derechos Fundamentales. Trad. Ernesto Garzón Valdés. Madrid: Centro de Estudios Constitucionales. 1986.

AVOLIO, Luiz Francisco Torquato. Provas llícitas: interceptações telefônicas e gravações clandestinas, atualizada em face da lei no 9.296/1996 e da jurisprudência. 2. ed. São Paulo: Revista dos Tribunais, 1999.

BARROS, Suzana de Toledo. Princípio da Proporcionalidade e o Controle de Constitucionalidade das Leis Restritivas de Direitos Fundamentais. 3. ed. Brasília: Brasília Jurídica, 2003. 
BITAR, Orlando. Obras Completas de Orlando Bitar. Rio de Janeiro: Renovar, 1996. v. 1.

BRASIL. Constituição (1988). Constituição da República Federativa do Brasil. Disponível em:〈http://www.planalto.gov.br/ccivil_03/Constituicao/Constituiçao.htm>. Acesso em: 25 abr.2010.

. Decreto-lei $n^{\circ}$ 2.848, de 7 de Dezembro de 1940. Código Penal. Disponível em: 4 ttp://www.planalto.gov.br/CCIVIL/Decreto-Lei/Del2848.htm>. Acesso em: 25 abr. 2010.

BUENO, Cássio Scarpinella. Curso Sistematizado de Direito Processual Civil. São Paulo: Saraiva, 2007. v. 1.

CANOTILHO, José J. Gomes. Direito Constitucional e Teoria da Constituição. 5. ed. Coimbra: Almedina, 2002.

CASTRILO, Eduardo de Urbano; M ORATO, Miguel Ángel Torres. La Prueba llícita Penal. 4. ed. Madrid : Arazandi, 2007.

CASTRO, Carlos Roberto Siqueira. O Devido Processo Legal e os Princípios da Razoabilidade e da Proporcionalidade. 4. ed. Rio de Janeiro: Forense, 2006.

DANTAS, David Diniz. Interpretação Constitucional no Pós-Positivismo: teoria e casos práticos. 2. ed. São Paulo: Madras, 2005.

FERREIRA, Luís Pinto. Comentários à Constituição Brasileira. São Paulo: Saraiva, 1995. v. 1.

GODOY, Evandro Carlos. Uma Aproximação das Concepções de Lógica de Kant e Frege. Disponível em: $\quad$ ettp://cascavel.cpd.ufsm.br/tede/tde_busca/arquivo.php?cod Arquivo $=1479>$. Acesso em: 16 jan. 2009.

GOM ES FILHO, Antônio Magalhães. Direito à Prova no Processo Penal. São Paulo: Revista dos Tribunais, 1997.

GRINOVER, Ada Pellegrini. Liberdades Públicas e Processo Penal: as interceptações telefônicas. 2. ed. São Paulo: Revista dos Tribunais, 1982.

GRINOVER, Ada Pellegrini; FERNANDES, Antonio Scarance; GOMES FILHO, Antonio M agalhães. Nulidades no Processo Penal. 7. ed. São Paulo: Revista dos Tribunais, 2001.

KANT, Immanuel. Fundamentação da M etafísica dos Costumes e Outros Escritos. São Paulo: Martin Claret. 2003.

LYCURGO, Tassos; ERICKSEN, Lauro. Filosofia do Direito. Bauru: Edipro, 2011. 
M ACHADO, Antônio Alberto. Curso de Processo Penal. 2. ed. São Paulo: Atlas, 2009.

MENDES, Gilmar, COELHO, Inocêncio Mártires, BRANCO, Paulo Gustavo Gonet. Curso de Direito Constitucional. 2. ed. São Paulo: Saraiva, 2008.

$\overline{2} 000$.

. Hermenêutica Constitucional e Direitos Fundamentais. Brasília: Brasília Jurídica,

MENDONÇA, Andrey Borges. Nova Reforma do Código de Processo Penal: comentada artigo por artigo. 2. ed. São Paulo: M étodo, 2009.

NERY JÚNIOR, Nelson. Princípios do Processo Civil na Constituição Federal. 3. ed. São Paulo: RT, 1996.

PEDROSO, Fernando de Almeida. Prova Penal: prova ilícita, prova por precatória, depoimento infantil, declarações da vítima, reconhecimento fotográfico. Rio de Janeiro: Aide, 1994.

PERELMAN, Chaïm. Lógica Jurídica: nova retórica. Trad. Vergínia K. Pupi. 2. ed. São Paulo: Martins Fontes, 2004.

RANGEL, Paulo. Direito Processual Penal. 16. ed. Rio de Janeiro: Lumen Juris, 2009.

SILVA, Germano Marques da. Curso de Processo Penal. 3. ed. Lisboa: Verbo, 1996. v. 1.

SILVA, José Afonso da. Curso de Direito Constitucional Positivo. 22. ed. São Paulo: Malheiros, 2006.

SILVA JÚNIOR, Walter Nunes. Curso de Direito Processual Penal: teoria (Constitucional) do Processo Penal. Rio de Janeiro: Renovar, 2008.

ZOLLINGER, Márcia. Proteção Processual aos Direitos Fundamentais. Salvador: JusPODIVM, 2006.

Artigo recebido em:

15 jul. 2011

Artigo aprovado em:

20 out. 2011 